\title{
COMPARISON OF CONVENTIONAL AND AUTOMATIC MILKING SYSTEMS AT EXTREME CONDITIONS BY THERMOGRAPHIC METHOD
}

\author{
Jiří ŠEVČÍK*, Daniel FALTA, Kristina SOMERLÍKOVÁ, Jiř̌i FRYČ \\ Mendel University in Brno, Czech Republic
}

\begin{abstract}
The objective of this study is to evaluate the impacts of teat traumatization on Holstein cows caused by two different types of milking systems (CMS - conventional milking system and AMS - an automatic milking system). The experiments were performed in two locations: at Žabčice School Farm of Mendel University in Brno and at ZEMAX, a. s. in Šitbořice. For the evaluation of the degree of traumatization, thermographic images depicting surface temperatures of teats were used. This paper tested the hypothesis that, at extreme conditions, the teat traumatization of Holstein cows does not depend on used milking system. The hypothesis was disproved by the performed monitoring. From statistical point of view, it was observed that there were significant differences depending on which milking system was used.
\end{abstract}

Keywords: AMS - automatic milking system; CMS - conventional milking system; heat stress; teat traumatization

In recent years, there has been a number of significant changes in dairy production within the Czech Republic. The first milking robot in the Czech Republic was installed at the farm Selekta Pacov Inc. in November 2003 (Havlík, 2007). Opinions on this new milking technology vary among agricultural practisers, experts and researchers not only in this country, but also abroad. The major difference between conventional milking system (CMS) and automatic milking system (AMS) lies in the motivation for cows to enter the milking stall. In CMS, the cows are driven to the milking parlour two to three times per day. In AMS, the cows enter the milking stall voluntarily and are milked throughout the day without human intervention (Weiss et al., 2004).

With climate changes, there is an increase in the quantity of days when the cows are exposed to heat stress. Therefore, this thesis examines the impacts of the milking systems during extreme conditions. The influence of the environment can not be ignored, as it can cause stress and thus negatively affect the condition of the organism (Fraser and Broom, 1990; Šoch et al. 2000, 2005). High ambient heat and humidity have profound effects on the production, health, profitability, and welfare of dairy cattle (Shock et al., 2016). By altering the thermal environment for livestock, climate change could affect the costs and returns of animal production - thereby affecting the animal health, reproduction, and the efficiency with which livestock convert feed into retained products (especially meat and milk). Extremely low and high temperatures have a negative impact on dairy cows. The impacts of low temperatures were observed by several experiments (Angrecka and Herbut, 2015; Brouček et al., 1991), while Brouček et al. (Brouček et al., 2006), Noordhuizen and Bonnefoy (Noordhuizen and Bonnefoy, 2015) and other authors were focused on impacts of extremely high temperatures. For dairy cows, the exposure to higher temperatures causes the decrease in milk output and reduces the content percentages of fat, solids, lactose, and protein in milk (Kadzere et al., 2002; St-Pierre et al., 2003; West, 2003). Dairy cows react to stress variously by: decrease in feed intake and increase in water intake, changes in metabolic rate and maintenance requirements, increased water loss caused by evaporation, increase in respiration rate, changes in hormone concentration in blood and increased body temperature (Knížková and Kunc, 2002).

Because the heat stress also reduces the fertility of cattle and thus reduces the reproduction rates, a solution might be lying in opting for breeds of cattle that are better suited to high temperatures. The welfare of dairy cows can be evaluated on the basis of the temperature - humidity index $(T H I)$ values. This index is commonly used as a practical indicator for the determination of stress degree on dairy cattle caused by weather conditions (Brouček et al., 2009). For example, Sharma et al. (Sharma et al.,1983) found that Jerseys were more resistant to heat stress in terms of milk production than Holsteins. Temperature variations within the range from $-0.5^{\circ} \mathrm{C}$ to $+25^{\circ} \mathrm{C}$ have insignificant impact on milk production (West, 2003). The assumed neutral temperatures for dairy cattle range from $-5{ }^{\circ} \mathrm{C}$ to $25{ }^{\circ} \mathrm{C}$ (Knížková et al., 2002). An upper critical temperature can be used as a point when an animal reaches the limit of its thermo-neutral zone and begins to experience stress due to heat. For example, the stated upper critical temperature for dairy cattle is usually $25-26{ }^{\circ} \mathrm{C}$ (Berman et al., 1985). According to Brouček et al. (Brouček et al., 2008), the upper critical temperature for Holsteins is $21^{\circ} \mathrm{C}$. At higher temperatures, the cows may show increase in respiration rate and decrease in voluntary feed intake. With decrease in feed intake, there comes decrease in milk output of up to 5 litres per day (Coufalík, 2013). 
Thermographic method was used for evaluation of milking techniques, because this method has been proven by many researchers. For example, Kunc (2009) states that the thermographic method for evaluating of the quality of the milking process is entirely comparable with other commonly used methods. For further research, we suggest thermographic method. Simplicity, non-destructive and non-contact approach and flexibility can be considered the undeniable advantages of this method.

The objective of this study was to evaluate the traumatization impacts of a CMS and AMS on teats at extreme conditions by thermographic method.

\section{Material and methods}

Two groups of dairy cattle have been monitored at the farms in Žabčice and Šitbořice. The selected farms were located close to each other (12 km), they breed the same type of dairy cattle and provide the same breeding conditions. Building design of constructions for livestock is also very similar. However, the identical conditions could not have been ensured. In order to increase the objectivity of the measurements, the large groups of animals were purposefully selected chosen with emphasis on high measurement count.

Firstly, there was carried out observation of teat traumatization at farm Žabčice, which is part of the Mendel University in Brno. Dairy cows are milked twice a day at milking intervals of 12 hours. Livestock production is focused on breeding cows with closed herd turnover. The average yearly milk production per farm is 8745 litres per cow. The average market production represents $94.56 \%$. Cows were milked through parlour ALFA LAVAL side by side $2 \times 14$. Average vacuum level was $43.1 \mathrm{kPa}$. In average, 550 cows are milked daily.
The second farm is ZEMAX Šitbořice, a.s. Agricultural production consists of breeding of Holstein cattle. Milking is performed by milking robots. Cows are voluntarily milked by four robots (LELY ASTRONAUT A2 and LELY ASTRONAUT A4) with free cow traffic to the AMS. Average vacuum level was $43.4 \mathrm{kPa}$. In contrast to CMS, cows milked by a robot are supposed to attend the milking station voluntarily. The average milking performed per cow is 2.7 times per day. The milking barn includes automatic ventilation. The average yearly milk production per farm is 9640 litres per cow. The average market production represents $95.3 \%$. In average, 270 cows are milked daily.

Both indoor and outdoor temperatures, as well as relative humidity and air velocity inside the stable were measured during the experiments. The values were measured at an interval of 30 minutes and mean values were calculated from the obtained data. Thermographic method was used to measure the surface temperature of the cow teats, at first after the cows' arrival to milking parlour, then after washing the teats and at last after removing the teat cups. The changes in the mean values of the teat surface temperature have been evaluated. There has been performed 40 measurements in each stall. CameraFLIR ThermaCAM EX320 was used to capture the thermographic images. Ambient temperature was measured by means of glass mercury thermometer. The relative humidity was measured by means of hair hygrometer 899 of laboratory type (Žiara Zvolen, Slovak Republic). Air velocity was measured by means of an anemometer Testo 417. Software FlirTools version 5.6 was used to evaluate thermographic images. There are two possible ways of how to determine the mean temperature in the selected area. The first possibility allows us to observe the area of a square or rectangle; and the second possibility allows us to observe surface in the shape of a circle or ellipse. For our experiment, the most suitable

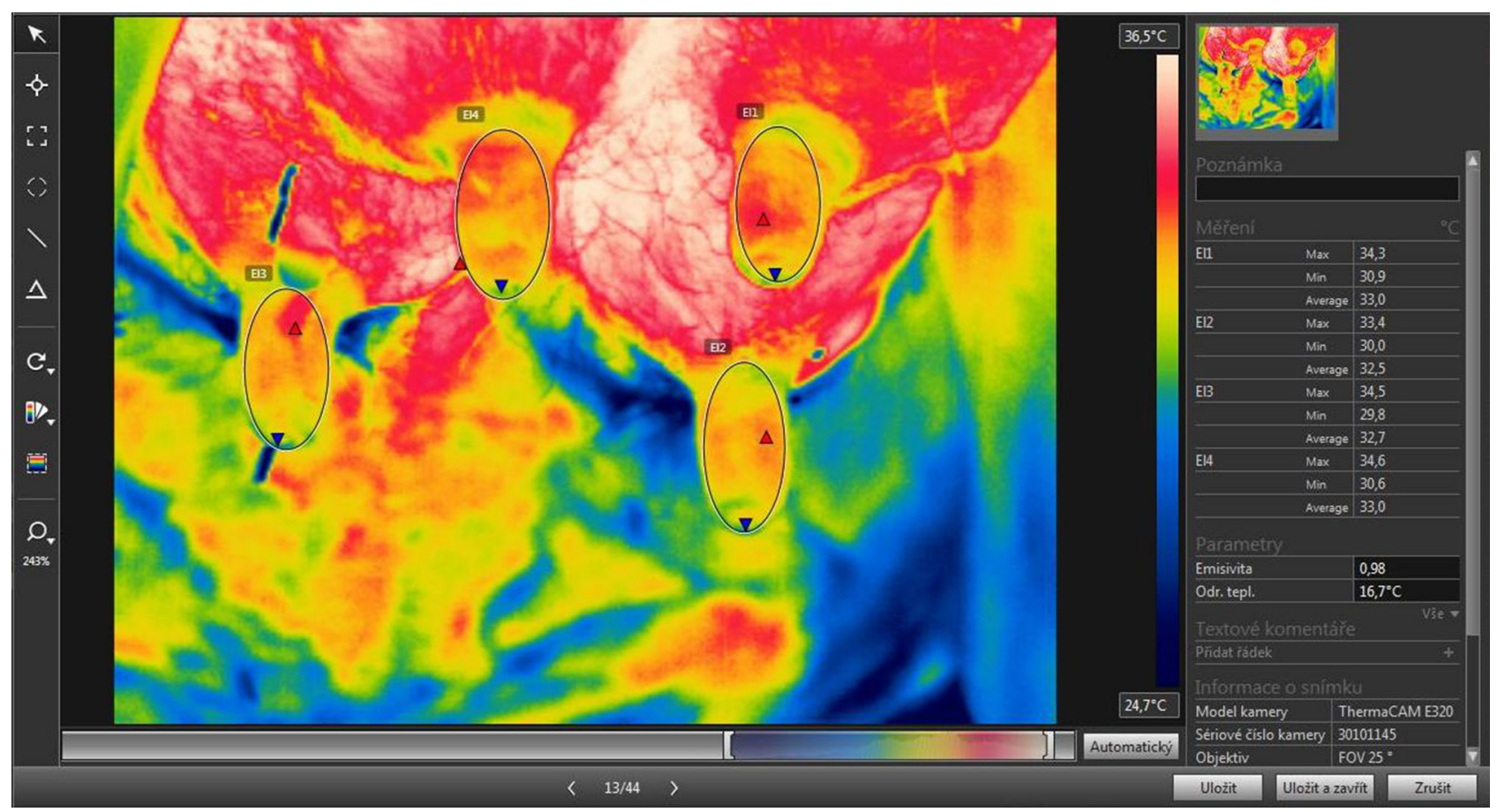

Figure 1 Thermographic images of the udder and teats 
shape is an ellipse, because it covers almost the entire surface of the teat as shown in Figure 1.

For the documentation of environmental impacts on dairy cow, THI index was calculated in 2015. Air temperatureand relative humidity were recorded at a climatological station of the Department of Agrosystems and Bioclimatology of Mendel University in Brno that is situated within testing area "Obora". It is located in the DyjeSvratka ravine. Measurements at farm Žabčice followed the methodology of the Czech Hydro-meteorological Institute (Slabá, 1972; Fišák, 1994).

THI was calculated according to Brouček et al. (2006) (1):

$$
T H I=0.8 \cdot T_{\max }+\frac{R H}{100}\left(T_{\max }-14.4\right)+46.4
$$

where:

$T_{\max }$ - maximum temperature per day $\left({ }^{\circ} \mathrm{C}\right)$

$R H$ - average relative humidity per day $(\%)$

From the point of view of heat stress, the mean values $T H I<70$ are considered thermo-neutral; the values $70 \leq \mathrm{THI}<72$ represent mild heat stress (MHS); the values $72 \leq \mathrm{THI}<78$ represent heat stress $(\mathrm{HS})$; and the values $T H I \geq 78$ represent severe heat stress (SHS).

For statistical evaluation of the results, the program Statistica $\mathrm{Cz}$ ver. 12 (StatSoft) was used. The paired t-test was used to determine the significance of the differences.

\section{Results and discussion}

Measurements were performed during the same day. At the farm Žabčice, there were following conditions: average outdoor temperature $30.5^{\circ} \mathrm{C}$, average outdoor relative humidity $54.0 \%$, average temperature in the stable $32.6{ }^{\circ} \mathrm{C}$, average relative humidity in the barn $52.5 \%$, average temperature in the milking parlour $33.8^{\circ} \mathrm{C}$, average relative humidity in the milking parlour $59.5 \%$, air velocity in the barn was lesser than $0.4 \mathrm{~m} \mathrm{~s}^{-1}$. At the farm Šitbořice, there were following conditions: average outdoor temperature $31.2{ }^{\circ} \mathrm{C}$, average outdoor relative humidity $52.2 \%$, average temperature in the stable $31.7^{\circ} \mathrm{C}$, average relative humidity in the barn $51.8 \%$, air velocity in the barn was lesser than $0.4 \mathrm{~m} \mathrm{~s}^{-1}$.

The following changes in teat surface temperature during the milking $\Delta T$ have been observed. At the farm Žabčice, cleaning routine before milking decreased the teat temperature of $2.35 \mathrm{~K}$; at farm Šitbořice, this decrease was of approximately $2.56 \mathrm{~K}$. The temperature decrease was larger by $0.21 \mathrm{~K}$ at farm Šitbořice, but the difference is not statistically significant $(P>0.05)$ as shown in Table 1.
During milking, there was an increase in the teat temperature of approximately of $3.44 \mathrm{~K}$ at the farm Žabčice; at the farm Šitbořice, the temperature increase was approximately of $2.95 \mathrm{~K}$. The average increase at the farm Šitborice was lower by approximately $0.49 \mathrm{~K}$. The difference was statistically significant $(P<0.05)$ as shown in Table 1.

The total difference between the teat temperatures before washing and after milking demonstrates that there was an increase in teat temperature of approximately $1.09 \mathrm{~K}$ at the farm Žabčice; at the farm Šitbořice, this increase was approximately of $0.38 \mathrm{~K}$. The average increase at the farm Šitborice was lower by approximately $0.71 \mathrm{~K}$ and the difference was statistically significant $(P<0.05)$ as shown in Table 1. The changes in teat surface temperature during the milking process was higher at farm Žabčice while using CMS. We conclude that the teat traumatization at heat stress

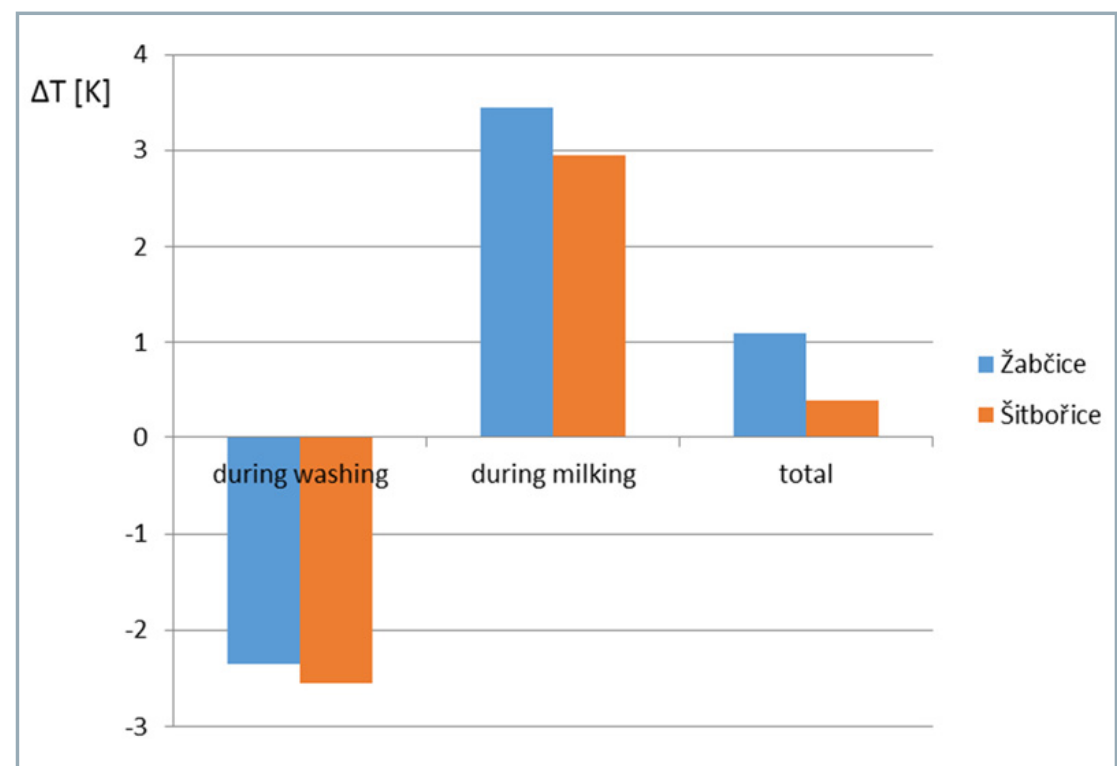

Figure 2 Changes of the teats temperature $\Delta T(\mathrm{~K})$

Table 1 Statistical differences and significance

\begin{tabular}{|l||c|c|c|c|c|c|}
\hline \multirow{2}{*}{ Farm } & \multicolumn{2}{|c|}{ Washing } & \multicolumn{2}{c|}{ Milking } & \multicolumn{2}{c|}{ Total } \\
\cline { 2 - 7 } & $\Delta \boldsymbol{T}(\mathbf{K})$ & SD & $\Delta \boldsymbol{T}(\mathbf{K})$ & 0.79 & 1,09 & 0.55 \\
\hline \hline Žabčice & -2.35 & 1.03 & 3.44 & 0.49 & 0.38 & 0.88 \\
\hline Šitbořice & -2.56 & 1.04 & 2.95 & & 0.71 & \\
\hline Difference & 0.21 & & 0.49 & $\mathrm{~S}$ & \\
\hline Significance & NS & & $\mathrm{S}$ & & & \\
\hline
\end{tabular}

$\Delta \mathrm{T}$ : average temperature difference; SD: standard deviation; NS: not significant; S: significant 
Table 2 Mean values of meteorological data in 2015 with respect to months

\begin{tabular}{|l||c|c|c|c|c|}
\hline Month & Average $\mathbf{T}\left({ }^{\circ} \mathbf{C}\right)$ & $\boldsymbol{T}_{\text {min. }}\left({ }^{\circ} \mathbf{C}\right)$ & $\left.\boldsymbol{T}_{\text {max. }}{ }^{\circ} \mathbf{C}\right)$ & $\boldsymbol{R H}$ (\%) & THI \\
\hline January & 1.82 & -5.93 & 16.50 & 88.57 & 42.12 \\
\hline February & 1.64 & -6.02 & 11.30 & 85.71 & 43.52 \\
\hline March & 5.46 & -5.27 & 17.86 & 76.28 & 53.21 \\
\hline April & 10.11 & -5.59 & 26.79 & 66.67 & 62.58 \\
\hline May & 14.66 & 2.54 & 25.89 & 75.55 & 67.75 \\
\hline June & 19.06 & 4.92 & 32.21 & 71.69 & 75.85 \\
\hline July & 22.93 & 5.38 & 37.68 & 66.07 & 82.20 \\
\hline August & 23.58 & 8.41 & 39.11 & 67.79 & 81.81 \\
\hline September & 15.92 & 2.40 & 33.10 & 74.99 & 69.18 \\
\hline October & 9.57 & -3.85 & 22.09 & 87.10 & 56.85 \\
\hline November & 6.21 & -5.93 & 20.95 & 88.17 & 52.81 \\
\hline December & 2.87 & -6.21 & 12.23 & 96.02 & 42.18 \\
\hline
\end{tabular}

Average $T$ - average temperature; $T_{\min .}$ - minimum temperature; $T_{\max }$ - maximum temperature; $R H$ - relative humidity; $T H I$ temperature-humidity index

exposure is lower when AMS is used. The results are shown in Figure 2.

Average temperature, relative humidity and calculated $T H I$ in 2015 are shown in Table 2. As depicted by the THI values, the heat stress exposure occurred in the months of June (75.85), July (82.20) and August (81.81) in 2015. This means that environmental conditions in other months were not considered heat stressful.

Our results are consistent with the studies of other researchers. Comparisons have been made between different AMS and CMS farms before and after the introduction of AMS. Several researchers have compared the impacts of AMS and CMS on cows' health. Hopster et al. (2002) reported that cows milked by AMS had a lower heart rate, suggesting that they are exposed to lower level of stress during milking. Authors Linčinskaja et al. (2010) concluded that the teat surface temperature before milking is lower than after milking. Results are consistent with studies of foreign scientists (Berry et al., 2003; Paulrud et al., 2005). Total difference between the teat temperature before washing and after milking was lower than results provided by Hanusová et al. (2016). It was probably caused by higher temperature in stable.

\section{Conclusion}

We observed two groups of cows in the same area under approximately the same conditions. With climate changes, there is increase in the quantity of days, during which the cows are exposed to heat stress. Therefore, this paper examines the impacts of the milking systems during extreme conditions. We observed the impacts of two milking systems (CMS and AMS) on teat temperature. The difference between measured values of teat surface temperature during the washing is not significant from the statistical point of view. During milking, there was observed an increase in teat temperature lower by about $0.49 \mathrm{~K}$ at the farm using AMS. The difference was statistically significant. Total difference (increased temperature) between the teat temperatures before washing and after milking was lower by approximately $0.71 \mathrm{~K}$ at the farm using AMS. The difference was statistically significant. From our study, we conclude that the teat traumatization during exposure to heat stress is lower when using AMS.

\section{Acknowledgements}

This study was financed by the Internal Grant Agency of the Faculty of Agronomy MENDELU in Brno No. TP 8/2014.

The authors thank to Mr. Brotan from Department of Agrosystems and Bioclimatology of Mendel University in Brno for providing the weather data. We would also like to thank to Mrs. Řeřábková and Mr. Ondrášek for their valuable help in organizing the experiment.

\section{References}

ANGRECKA, S. - HERBUT, P. 2015. Conditions for cold stress development in dairy cattle kept in free stall barn during severe frosts. In Czech J. Anim. Sci., vol. 60, 2015, no. 2, pp. 81-87.

BERMAN, A. - FOLMAN, Y. - KAIM, M. - MAMEN, M. - HERZ, Z. WOLFENSON, D. - ARIELI, A. - GRABER Y. 1985. Upper critical temperatures and forced ventilation effects for high-yielding dairy cows in a subtropical climate. In J. Dairy Sci., vol. 68, 1985, no. 6, pp.1488-1495.

BERRY, R. J. - KENNEDY, A. D. - SCOTT, S. L. - KYLE, B. L. - SCHAEFER, A. L. 2003. Daily variation in the udder surface temperature of dairy cows measured by infrared thermography: Potential for mastitis detection. In Canad. J. of Animal Science, vol. 83, 2003, no. 4, pp. 687-693.

BROUČEK, J. - LETKOVIČOVA, M. - KOVALCUJ, K. 1991. Estimation of cold stress effect on dairy cows. In International Journal of Biometeorology, vol. 35, 1991, pp. 29-32.

BROUČEK, J. - MIHINA, Š. - RYBA, Š. - TONGEL, P. - KIŠAC, P. UHRINČĂ̌, M. - HANUS, A. 2006. Effects of high air temperatures on milk efficiency in dairy cows. In Czech J. Anim. Sci., vol. 51, 2006, no. 3, pp. 93-101.

BROUČEK, J. - NOVÁK, P. - VOKŘÁLOVÁ, J. - ŠOCH, M. - KIŠAC, P. UHRINČAT̆, M. 2009. Effect on hight tempreture on milk production of cows from free-stall housing with natural ventilation. In Slovak J. Anim. Sci., vol. 42, 2009, no. 4, pp 167-173. 
COUFALÍK, V. 2013. Současné problémy v reprodukci skotu. Olomouc: Agriprint, 2013. 181 pp. ISBN 978-80-87091-46-3.

DAVIS, M. A. - REINEMANN, D. J. 2000. Milking Performance and Udder Health of Cows Milked Roboticaly and Conventionally. ASA Meeting Presentation, Paper Number 02-3112, Chicago, Illionis, USA.

FIŠÁK, J. 1994. Metodický předpis č. 11: Návod pro pozorovatele meteorologických stanic ČHMÚ. $3^{\text {rd }}$ ed. Praha : ČHMÚ, 1994. 115 pp. ISBN 80-85813-12-2.

FRASER, A.F. - BROOM, D.M. 1990. Farm animal behaviour and welfare. 1990. pp. 256-265.

HANUSOVÁ, J. - GÁLIK, R. - BOĎO, Š. - KUNC, P. - KNÍŽKOVÁ, I. - STARŇOVÁ, L. 2016. Analysis of quality milking process by thermographic metod. In Acta Universitatis Agricilturae et Silviculturae Mendelianae Brunensis, vol. 64, 2016, no. 4, pp. 1149-1153.

HAVLÍK, V. 2007. Dojicí roboty Lely Astronaut ve světě a v České republice. In Náš chov, vol. 1, 2007, pp. 31-32.

HOPSTER, H. - BRUCKMAIER, R. M. - VAN DER WERF, J. T. N. - KORTE, S. M. - MAČUHOVA, J. - KORTE-BOUWS, G. - VAN REENEN, C. G. 2002. Stress responses during milking: Comparing conventional and automatic milking in primiparous dairy cows. In Journal of Dairy Science, vol. 85, 2002, no. 12, pp. 3206-3216.

KADZERE, C. - MURPHY, M. - SILANIKOVE, N. - MALTZ, E.2002. Heat Stress in Lactating Dairy Cows: A Review. In Livestock Production Science, vol. 77, 2002, no. 1, pp. 59-91.

KNÍŽKOVÁ, I. - KUNC, P. 2002. The influence of water evaporative cooling on haematological parameters in dairy cows during heat stress. In Folia Vet., vol. 46, 2002, pp. 18-19.

KNÍŽKOVA, I. - KUNC, P. - KOUBKOVA, M. - FLUSSER J. - DOLEZAL O. 2002. Evaluation of naturally ventilated dairy barn management by a thermographic method. In Livestock Production Science, vol. 77, 2002, pp. 349-353.

KUNC, P. 2009. Využití infračervené termografie $k$ hodnocen procesu strojního dojení: Habilitation thesis. Praha : VÚŽV, 2009.

LINČINSKAJA, A. K. - BARKOVA, A. S. - KOLČINA, A. F. 2010. Перспективы применения инфракрасной термографии в исследовании молочной железы коров. I Аграрный вестник Урала, vol. 75, 2010, no. 9-10, pp. 32-34.
NOORDHUIZEN, J. - BONNEFOY, J. M. 2015. Heat Stress in Dairy Cattle: Major Effects and Practical Management Measures for Page 7 of 7 Prevention and Control. In SOJ Vet Sci, vol. 1, 2015, no. 1, p. 103.

PAULRUD, C. O. - CLAUSEN, S. - ANDERSEN, P. E. - RASMUSSEN, M. 2005. Infrared Thermography and Ultrasonography to Indirectly Monitor the Influence of Liner Type and Overmilking on Teat Tissue Recovery. In Acta vet. Scand., vol. 46, 2005, no. 3, pp. 137-147.

SHARMA, A. K. - RODRIGUEZ, G. - MEKONNEN, C. J. - WILCOX, K. C. - BACHMAN, A. - COLLIER, R. J. 1983. Climatological and genetic effects on milk composition and yield. In Journal of Dairy Science, vol. 66, 1983, no. 1, pp. 119-126.

SHOCK, D. A. - LEBLANC, S. J. - LESLIE, K. E - HAND, K. - GODKIN, M. A. - COE, J. B. - KELTON, D. F. 2016. Studying the relationship between on-farm environmental conditions and local meteorological station data during the summer. In Journal of Dairy Science, vol. 99, 2016, no. 3, pp. 2169-2179.

SLABÁ, N. 1972. Návod pro pozorovatele meteorologických stanic ČSSR. $2^{\text {nd }}$ ed. In Sborník předpisů, Praha : HMÚ, 1972. 224 pp.

ST-PIERRE, N. R. - COBANOV, B. - SCHNITKEY, G. 2003. Economic Loss from Heat Stress by U.S. Livestock Industries. In Journal of Dairy Science, vol. 86, 2003, E Suppl., pp. E52-E77.

ŠOCH, M. 2005. Effect of environment on selected indices of cattle welfare. Scientific monograph. České Budějovice : Jihočeská univerzita v Českých Budějovicích, 2005. 288 pp.

ŠOCH, M. - NOVÁK, P. - ŘEHOUT, V. - VRÁBLÍKOVÁ, J. - TRÁVNÍČEK, J. -MATOUŠKOVÁ, E. 2000. In Welfare of Farm Animal, 2000. pp. 99 102. ISSN 1212-558X.

WEISS, D. - HELMREICH, S. - MOSTL, E. - DZIDIC, A. - BRUCKMAIER R. M. 2004. Coping capacity of dairy cows during the change from conventional to automatic milking. In J. Anim. Sci., vol. 82, 2004, pp. 563-570.

WEST, J. W. 2003. Effects of Heat-Stress on Production in Dairy Cattle. In Journal of Dairy Science, vol. 86, 2003, no. 1, pp. 2131-2144. 